2019-8

\title{
Amphibious Entrepreneurs and the Origins of Invention
}

\author{
Kurt Sandholtz \\ sandholtz@byu.edu \\ Walter W. Powell
}

Follow this and additional works at: https://scholarsarchive.byu.edu/facpub

Part of the Entrepreneurial and Small Business Operations Commons

\section{Original Publication Citation}

Sandholtz, Kurt W. and Walter W. Powell (2019). "Amphibious Entrepreneurs and the Origins of Invention," in Jeff Reuer and Sharon Matusik (eds.) The Oxford Handbook on Entrepreneurship and Collaboration. Oxford University Press. pp. 541-566. doi: 10.1093/oxfordhb/ 9780190633899.013 .37$.

\section{BYU ScholarsArchive Citation}

Sandholtz, Kurt and Powell, Walter W., "Amphibious Entrepreneurs and the Origins of Invention" (2019). Faculty Publications. 3602.

https://scholarsarchive.byu.edu/facpub/3602 


\title{
Amphibious Entrepreneurs and the Origins of Invention
}

\author{
Kurt Sandholtz \\ Brigham Young University
}

Walter W. Powell

Stanford University

Full reference:

Sandholtz, Kurt W. and Walter W. Powell (2019). “Amphibious Entrepreneurs and the Origins of Invention," in Jeff Reuer and Sharon Matusik (eds.) The Oxford Handbook on Entrepreneurship and Collaboration. Oxford University Press. pp. 541-566. doi: 10.1093/oxfordhb/9780190633899.013.37. 


\begin{abstract}
In this chapter, we examine entrepreneurs who carry ideas, technologies, values, and assumptions between previously unrelated spheres of economic or cultural activity, and in the process, change the existing order of things. We label such individuals amphibious entrepreneurs and explore their characteristics via four case studies. Their stories suggest a distinct species within the genus of entrepreneur: more pragmatic than heroic, and as likely to invent by not knowing any better as by calculative creation. We discuss their role in creating interstitial spaces, contrast them to other boundary-spanning actors, and identify directions for future research at the intersection of social history and entrepreneurship.
\end{abstract}

Keywords: novelty, invention, amphibiousness, pragmatism, interstitial spaces, boundary spanning, social history, emergence 


\section{INTRODUCTION}

When and why do new kinds of organizations emerge, take root, and persist? The lack of consensus on this fundamental question suggests that the emergence of novelty, especially of new categories of people and organizations, is undertheorized in the social sciences.

Explanations of novelty tend to rely on either opportunities created by external shocks or the insights of unusually talented, creative people. With the former line of thought, the difficulty lies in pinpointing how social upheavals, technological disruptions, or regulatory changes open up opportunities for new practices in organizations. The latter approach begs the question of why some supremely talented, creative people seize particular moments, whereas others fail and are retrospectively labeled as "ahead of their time."

We offer a pragmatist account of the emergence of novelty (Cohen 2007; Gilson, Sabel \& Scott 2009; Stark 2009). Our perspective highlights the role of amphibious entrepreneurs: people who simultaneously inhabit multiple social worlds, which affords them the chance to staple together contradictory principles (Powell \& Sandholtz 2012a). People carry skills and networks with them as they move through the life course. We argue that innovation and invention can result from the intersection of people, their biographies, and the multiple networks in which they are embedded (Padgett \& Powell 2012).

Our theory of amphibious entrepreneurship begins with two basic premises. First, the amphibious entrepreneur is deeply immersed in the practices, values, and perspectives of a particular domain or social world. Second, the amphibious entrepreneur moves from this domain of immersion to another in which his or her ingrained practices, values, and perspectives are unknown, alien, and perhaps even heretical. These relatively simple initial conditions are rife with possibilities for radical novelty but are more likely to result in extinction than innovation, 
precisely because such novelty can be opposed by traditionalists from both sides. But when transposed practices and values incubate and survive in a new domain, ensuing changes may spill over and reverberate into distant domains, unleashing large-scale changes in society. We use this chapter to explore these ideas.

\section{What is an amphibious entrepreneur?}

The word amphibian comes from the Greek amphi, meaning both, and bios, meaning life. Originally, it referred to "living both in water and on land." Its figurative meaning stems from the mid-17th century, when amphibian was first used to describe a person "having two modes of existence or a double character" (Oxford English Dictionary). This duality is central to our definition of an amphibious entrepreneur: someone who carries social skill and human capital from one domain into another, and in the process creates novel practices and organizational models which have the potential to generate whole new lines of activity. The amphibian creates novelty in two forms: First, innovation can result from the assembly of new types of ties out of combinations among old ties (a familiar outcome of brokerage). Second, and more radical, invention can be catalyzed through the tipping of an entire ecology of multiple networks as innovations trigger chain reactions of novelty (Padgett \& Powell 2012).

Consider two examples of the radical novelty we term invention. Both illustrate the process of transposition through which formerly unassociated practices and ideas are combined and result in new kinds of action. The first is now widely familiar, mythologized by the book and movie Moneyball (Lewis 2003). Billy Beane, general manager of Major League Baseball's Oakland A's, found himself in a quandary in the mid-1990s. The club's owner wouldn't spend money for top players yet wanted to field a competitive team. Beane coupled academic financial models with arcane player statistics called "sabermetrics" to calculate the value of players who had 
cheap contracts but contributed to their team winning more games. Beane's computational approach paid off. From 1999 to 2008, the A's won more games than all but three teams: the New York Yankees, the Boston Red Sox, and the Atlanta Braves. The average annual payroll for these three teams was $\$ 119$ million; for the A’s, it was $\$ 48.5$ million. The Yankees, Red Sox, and Braves paid \$1.27 million per win during this era; the A’s paid $\$ 538,600$. Such efficiency caught the attention of other small-market clubs. In 2008, the Tampa Bay Rays rode an analytically assembled team to the World Series with a payroll-per-win ratio of less than $\$ 452,000 .{ }^{1}$ Beane's statistical approach gained even greater validity when it was embraced by Theo Epstein, a Beane protégé and GM of one of the richest teams, the Boston Red Sox, who won the World Series in 2004, 2007, and 2013.

Today, every Major League team has a deep statistical staff. How the game is played has been altered by analytics, and the backlash against sabermetrics by seasoned veterans has been defeated. The changes were not confined to the world of baseball, however, or even to the world of sports. Moneyball is standard reading in business schools. The sabermetric revolution has led to a broader focus on people analytics (Baumer \& Zimbalist 2015). Statistics about the spin rate of pitches and the exit velocity of baseballs as they come off the bat have parallels in the corporate world, such as statistical analyses of team formation and staff retention. Google's People Analytics department is the poster child for such practices. For example, the company has changed how it recruits, no longer using brainteasers in interviews because the stats show that the ability to solve such puzzles does not predict job performance. For the same reason, GPA is no longer considered for anyone more than two years out of college. The analytics movement

\footnotetext{
${ }^{1}$ Data for these analysis are from two sources. Wins per season are found at Baseball Reference (https://www.baseball-reference.com/leagues/MLB/index.shtml). Opening-day payrolls are found at Steve the Ump.com (http://www.stevetheump.com/Payrolls.htm\#team payrolls).
} 
originated in academic finance, spread to baseball and other sports, diffused into industry, and reverberated back into the academy, where big-data analytics and computational social science have become popular university subjects. Beane stapled together deep knowledge of baseball with an appreciation for the utility of hard data, drawing on the Black-Scholes (1973) arbitrage pricing model. He supplemented traditional talent scouts with a new type of analyst: academics with $\mathrm{PhDs}$ in economics, applied math, or statistics but with no first-hand knowledge of baseball. The cascade of changes unleashed could never have been predicted from Beane's experience with the lowly Oakland A's. As Michael Lewis comments, "It's hard to think of anyone else like him. Billy burst out of baseball the way people in baseball really just don't” (Slusser 2017: All). A second example comes from the world of haute cuisine. Today, culinary invention is all the rage, but its origins can, in some sense, be traced to a small town in Catalonia where a young chef, Ferran Adrià, was given free reign at a small restaurant, El Bulli (Svejenova, Mazza, \& Planellas 2007). Since time immemorial, cooking has involved fire and heat. But drawing from the world of science, Adrià turned food creation into an R\&D lab. He borrowed techniques for using extreme cold (notably liquid nitrogen) and water baths to "cook" food differently. Initially, his transgressions were limited to his menu, on which soup appeared as a solid and rabbit as a liquid. His laboratory approach to running a kitchen encouraged the development of new practices and these changes were enacted in his organization, in both proactive and reactive ways (Opazo, 2016). The equipment and technologies that resulted fueled the growth of what has since been labeled "molecular gastronomy," an entirely new category of cuisine. Adrià drew heavily on advances in design and art to radically alter the way his food was presented. His restaurant featured a set meal presented for 180 days a year, replaced by an entirely new menu the following year. As the restaurant reached the pinnacle - voted best restaurant in the world five 
years in a row - he closed it. Adrià turned to teaching a course with chemists and physicists at Harvard University. He now promotes cooking as a form of national identity and economic development and has created a foundation modeled on the open source community.

These examples illustrate the potential for invention inherent in the collision of formerly distant social worlds. Black-Scholes and baseball? Molecular chemistry and food preparation? Such combinations were inconceivable until they happened. By all accounts, however, the front office of the Oakland A's and the founding partners of El Bulli were deliberate in their melding of disparate influences to consolidate a new form of knowledge in their respective fields. The engine of novelty was transposition, an acknowledged catalyst of large-scale change (Padgett \& McLean 2006; Vedres \& Stark 2010). Although the broader repercussions of Beane's and Adrià's efforts could not have been identified a priori, these two pioneers were traditional entrepreneurs, seeking to innovate in order to gain competitive advantage in their respective markets.

The idea of the amphibious entrepreneur differs in its emphasis on the role of naïveté in the emergence of novelty. More pragmatic than heroic, amphibious entrepreneurs are as likely to generate novelty by not knowing any better as by purposive, calculative creation. Their approach is simply to move forward with ingrained assumptions in new contexts and, in the process, generate something unprecedented. Thus, the amphibious entrepreneur is a distinct species within the genus of entrepreneur: less muscular or instrumental than is often depicted in the popular press or, sometimes, in the entrepreneurship literature.

\section{Research related to amphibious entrepreneurship}


The term "amphibious entrepreneur" first appeared in a pair of papers chronicling the origins of the biotech industry (Powell \& Sandholtz 2012a, 2012b). These studies analyzed the emergence of a new-to-the-world organizational form, the "dedicated biotech firm" (DBF), which was an odd amalgam of practices and values stapled together from the worlds of academic science, venture capital, and Big Pharma. The amphibians in these cases were renowned molecular biology and genetics faculty members who came to straddle the worlds of science and commerce, yet were naïve about the workings of industry. Indeed, many of their founding stories could be summarized by the phrase, "A funny thing happened on the way to getting my lab funded." Their default approach to organizing a startup company was to manage it the way they ran their university research labs: heavy emphasis on fundamental scientific inquiry; less attention to commercial success (indeed, many of these startups did not produce a profitable product that they distributed on their own); open collaboration with universities, non-profit research centers, and established pharmaceutical companies; and insistence on publishing scientific breakthroughs (after patenting them) rather than keep them secret. In effect, DBFs were elite research labs funded by venture capital. As some of these firms began to produce blockbuster drugs to treat previously untreatable diseases, the "oddball" practices that had been assembled by amphibious founders began to change how venture capitalists invested, the way Big Pharma conducted research, and the way academic scientists conducted their research and managed their careers. (A more complete account of the origins and impact of the biotech industry is available in Powell \& Sandholtz 2012a and 2012b.)

Building on these initial ideas, the concept of amphibiousness has been applied in a variety of settings. We briefly comment on three such applications. First, entrepreneurship research has started to explore the role of amphibious processes in the formation of new enterprises. For 
example, a recent review by Fisher, Kotha, and Lahiri (2016) unpacks an important aspect of amphibious entrepreneurship by examining how legitimacy in one domain can be transferred to a new domain. Such "stocks of legitimacy" can come from "the positive prior reputation of the people within the venture" (Fisher et al. 2016: 400; italics in original) - even if the entrepreneur's reputation is in a different arena. On the other hand, the practices and values from a prior domain can become a liability in the new domain. For example, the authors describe how as entrepreneurs "cross between academia and industry" they may "encounter the contradictory expectations of the scientific and business communities," leading not only to an identity crisis for the entrepreneurs but a legitimacy crisis for the new venture (Fisher et al. 2016: 396). Fisher et al. point out that such entrepreneurs must use these contradictory pressures to fashion new models of organizing or risk being pulled down by the constraints of existing protocols.

Second, Patriotta and Hirsch (2016) theorize how innovation occurs and becomes accepted in art worlds. They argue that innovation results from simultaneous changes in network structures and institutional categories. Structurally, unknown artists (“outsiders”) move from the periphery to the core of an art world as their ideas become more accepted, thus enabling them to gain access to resources. At the same time, existing artistic categories and conventions are questioned and new conventions legitimized as artistic "mavericks" become recognized as "mainstreamers." Patriotta and Hirsch (2016: 874) describe the role played by "amphibious artists," who can start out as either mainstreamers or mavericks: "We see these boundary spanners as less distant from mainstreamers, for while they are socially separated, they promote exchanges between core and periphery, and help expand mainstream conventions into new direction." Their illustrative case is the rise and acceptance of independent cinema in the U.S. Their amphibious artist is Robert Redford, an acclaimed mainstream actor, director, and producer, who lent legitimacy and 
resources to the world of independent cinema through his sponsorship and cultivation of the Sundance Film Festival. Originally an anti-Hollywood forum, the festival has grown into an international phenomenon that offers independent filmmakers access and exposure to major Hollywood studios. At the same time, Hollywood filmmaking has become more "indie" in its approach, incorporating into many of its large-budget projects the rawness and vibrancy associated with formerly peripheral artists (Perren 2012).

Third, research on social movements has begun to explore the emergence of "tactical innovation," defined as the creation or adoption of tactics that had not previously been used by established social movement organizations (Wang and Soule 2016). Analyzing more than 23,000 protest events in the U.S. from 1960 to 1995, Wang and Soule show that at events where formerly separate social issues were being protested - women's rights combined with gay/lesbian rights, for example - novel amalgams of disparate protest tactics were much more likely to be deployed. As the authors put it, "multi-issue protests can generate recombinatorial tactical innovation when multiple groups representing different interests join together" (Wang and Soule 2016: 522). Although this research does not explore the action of amphibious individuals or groups, the mechanism articulated has amphibious contours: "protest events that span dissimilar claims make it possible for participants to cross boundaries separating the tactical repertoires associated with different movements" (Wang \& Soule 2016: 537). The authors advocate future studies that examine these boundary-crossing processes at a more granular level in order to identify the role of individual protest leaders and social movement organizers in the emergence of novel tactics.

We are encouraged by the increasing overlap between research on social movements and entrepreneurship studies (Sine, Haveman, \& Tolbert 2005; Hiatt, Sine, \& Tolbert, 2009). An 
intriguing recent study in this vein is Mora's (2014) analysis of the emergence and creation of the pan-ethnic category of Hispanic. In 1970, the category of Hispanic or Latino did not exist in the U.S. Mexican Americans, Cubans, Puerto Ricans, Columbians, Guatemalans, and so on, came from different class backgrounds and had divergent immigrant experiences. By the mid1980s, however, they were united under the category Hispanic. How? Mora (2014) argues that "cross-field effects" made this new category of persons possible. The disparate efforts of political activists, Spanish-speaking media companies, advertisers, and the U.S. Census came together to create an unusual convergence. Bureaucrats, media execs, and political activists not only formed links with one another, but they transposed and exploited each other's frames. The television channel Univision transposed census data into a marketing manual and borrowed the "underrepresented minorities" frame from activists in appeals to TV regulators. In turn, activists used census and marketing data to depict Hispanics as a new political force. These recombinations came together as activists and executives borrowed frames that had been developed in different contexts to create a novel political and economic community.

More generally, social movement research helps us think about how different forms of boundary spanning can lead to novelty. Snow et al. (1986) developed the idea of frame extension to capture a process by which activists in one movement broaden their political goals to attract constituencies outside their core supporters. On occasion, such moves can create unexpected new political communities. More recently, Wang and Piazza (2016) analyze multi-issue protest events, which have the chance to garner more attention and support, but like any amphibious move, have the inherent difficulty of maintaining fidelity to multiple constituencies.

These studies evidence a fledgling scholarly literature examining amphibiousness as a catalyst of broader social novelty. Limitations in this literature include the relative paucity of illustrative 
cases in general, and the absence of failure cases in particular. The first limitation could foster criticism that amphibiousness is sui generis to the worlds of biotech or art. The second limitation leaves room for skepticism regarding success bias (although see Powell \& Sandholtz 2012b for a response to this criticism). In addition, to be a more useful construct, the dimensions of what amphibiousness is and is not need to be more clearly delineated.

To that end, we present four cases of amphibious entrepreneurship: Ed Catmull and the crossfertilization between computer science and big-budget filmmaking that created mass-market computer-animated films; Jacqueline Novogratz and the emergence of Acumen, a nonprofit venture capital firm; Carlos Santana and the invention of Latin rock, a new musical genre; and Victoria Hale, who created a nonprofit pharmaceutical company that fell short of disrupting both Big Pharma and the nonprofit world. After presenting the cases, we return to our definition of amphibious entrepreneurs, focusing on how amphibians create social interstices and drawing out the similarities and differences between amphibious entrepreneurs and other boundary-spanning roles.

\section{CASE STUDIES}

\section{Case 1: Ed Catmull and the birth of digital animation}

On November 22, 1995, Pixar's animated feature film Toy Story was released to critical acclaim. One week later, Pixar raised $\$ 140$ million in the largest IPO of 1995 . Animated filmmaking has never been the same. Pixar's blend of new-to-the-world technology and ages-old storytelling has had repercussions throughout Hollywood, resulting in the reinvention of Disney Animation and the entire animated film industry. Such large-scale impact is achieved through the efforts of thousands of people and millions of events, yet if any one individual set it in motion, it was Ed 
Catmull, a reluctant entrepreneur whose deep expertise in computer science, transposed to the world of movie making, catalyzed the digital revolution in animation.

Catmull grew up in Salt Lake City during the optimistic post-WWII years. His two childhood heroes were Albert Einstein and Walt Disney (Hollar 2013: 2), foreshadowing the blend of science and entertainment that would eventually shape Pixar. He loved drawing and was fascinated by animation, but he also excelled in math and science in high school. Unable to find a college that taught animation, he chose science, graduating with a double major in physics and computer science from the University of Utah.

After being laid off from a low-level programming job at Boeing, Catmull returned to Utah to pursue a $\mathrm{PhD}$. He chose computer science over physics because in computer science "we were at the frontier, whereas with physics ... you had another four to six years ahead of you to get to the frontier" (Hollar 2013: 6). Catmull was unaware that the university’s computer science department, led by David Evans and Ivan Sutherland, was breaking new ground in computergenerated graphics. As department chair, Evans' instinct was to create a rich, interdisciplinary environment with ample funding and plenty of freedom. Catmull recalls:

One of the interesting things about Utah at that ... it was the one place where both the fields [computer science and image processing] were together. And it was part of the development of computer graphics to have the image processing side alongside it. After that, at the universities they were not together. They tend to be in computer graphics and there's image processing. But Utah started off not only with them together, but, in the middle of the department they had a photography lab. So we had a professional photographer running this lab in the middle of the program to help make some pictures. (Hollar 2013: 9)

Catmull's first graduate course was a computer graphics seminar taught by Ivan Sutherland.

"There were no textbooks," Catmull remembers. "Ivan Sutherland came in wearing flip flops and I thought he was one of the hippie graduate students" (Hollar 2013: 7). In that seminar, Catmull 
wrote a program to digitize and animate his left hand. His work resulted in a paper published in the 1972 Proceedings of the ACM Annual Conference entitled "A System for ComputerGenerated Movies.” More importantly, the seminar helped Catmull crystallize his personal mission:

... fairly quickly I realized that there was incredible potential in making pictures. Those first pictures were black and white. They were polygonal. They had jaggies along the edges. They were very crude. Everything was crude. But you could see the computers are getting faster and that here's something to pursue. That's when I connected the dots to say, "Oh, I can use this for making art." And once I took that class, everything shifted. I was no longer pursuing computer languages. Everything was about, "How do I develop the technologies so that we can do curved surfaces and animate them and get us to the point where we can make movies with them?" (Hollar 2013: 8)

Note the focus of Catmull's vision: solving a thorny technical problem in order to create art. He was decidedly uninterested in traditional entrepreneurship; two of his Utah professors were in the throes of starting a company (the pioneering computer graphics firm, Evans \& Sutherland). Catmull witnessed the startup world and wanted no part of it. Instead, he interviewed for academic jobs but received no offers. Computer animation was too far out: "Each time I expressed that goal in job interviews at universities, it seemed to cast a pall over the room. 'But we want you to teach computer science,' my interviewers would say" (Catmull 2014: 20; italics in original). With few other options, he took a job in 1974 at Applicon, a small Boston-based computer-aided design company. In less than a year, however, he was recruited to build from scratch a computer animation research lab at the New York Institute of Technology.

NYIT had been founded by Alex Schure, an eccentric multimillionaire with a passion for using computers to make movies. He provided Catmull with cutting-edge equipment (purchased, appropriately, from Evans \& Sutherland), ample space, unlimited funding to hire bright people, and complete freedom. Catmull, of course, replicated the only management structure and culture he knew, that of the U of U's computer science department: "I created a flat organizational 
structure, much like I'd experienced in academia, largely because I naively thought that if I put together a hierarchical structure ... I would have to spend too much time managing and not enough time on my own work" (Catmull 2014: 24). He assembled a crack technical team to begin solving fundamental technical challenges. They published all of their findings - a stark contrast to commercially oriented competitors, who "embraced a culture of strictly enforced, even CIA-like secrecy." Catmull (2014: 25) explains:

My view was that we were all so far from achieving our goal that to hoard ideas only impeded our ability to get to the finish line. Instead, NYIT engaged with the computer graphics community, publishing everything we discovered, participating in committees to review papers written by all manner of researchers, and taking active roles at all the major academic conferences. The benefit of this transparency was not immediately felt (and, notably, when we decided upon it, we weren't even counting on a payoff; it just seemed like the right thing to do).

To this point, Catmull's biography amply illustrates the first condition for amphibious entrepreneurship: deep immersion in a particular social domain. Catmull and his group at NYIT produced a stream of research that laid the foundation for the field of computer animation (Hollar 2013: 15). The second condition - relocation to an utterly foreign domain - happened in 1979 when Catmull was recruited to run a newly formed computer animation group at Lucasfilm. Flush with the success of Star Wars (1977), George Lucas had the vision and the resources to push the frontiers of digital filmmaking. Such techniques were foreign to Hollywood at the time, however. Catmull, while running NYIT's animation lab, had made numerous overtures to the major studios, searching for a collaboration partner. As he puts it, "It's hard to imagine now, but in 1976, the idea of incorporating high technology into Hollywood filmmaking wasn't just a low priority; it wasn't even on the radar" (Catmull 2014: 25). 
At Lucasfilm, Catmull continued to staff and manage his animation group the only way he knew

how: like a university CS department. His approach continued to emphasize openness, research, and publishing:

... the foundations were put in place in Utah and then confirmed at New York Tech.... [T] he number of things that it takes to put together any development is just vast. If you look at it that way, what is the important thing you want? It's the people that keep coming up with ideas. And when we participated in the broader community, the computer graphics community and the film community, we were connecting with people. We were sharing ideas. We may have given away some of our secret ideas, but what we were getting back were ideas from other people. And a lot of those great people wanted to come work with us. So, when we came to Lucasfilm, I'd say a lot of people said they were coming not because it was Lucasfilm or even because it was Star Wars. It was because of this open group.

“. . . we continued to publish, and the company and George [Lucas] never had a problem with that. ... So we published lots and lots of papers. There were several years when more papers were from Lucasfilm than any place else. And we still do this at Pixar publish, go to the conferences, invite people here. It's bigger than any of us. Let's enjoy it." (Hollar 2013:18)

In essence, Catmull was running an elite academic research group within a for-profit corporation, buffered from economic realities by the extraordinary financial success of the Star Wars franchise. Lucasfilm felt "as protected as an academic institution," says Catmull (2014:29), “an idea that would stay with me and help shape what I would later try to build at Pixar." The protections vanished in 1983, when in the wake of George Lucas' divorce, Lucasfilm was cashstrapped and decided to sell its graphics division. Catmull's group struggled for three years to find a buyer; their only product was a high-end piece of hardware (the Pixar Image Computer) that lacked a clearly defined market. At the brink of disbanding, the graphics group was rescued by Steve Jobs, who purchased them from Lucasfilm for $\$ 5$ million in 1986. Pixar was born, but on life support. Catmull's academia-influenced modus operandi was not well suited to running a product business. Were it not for Jobs' cash and deal-making prowess, Pixar would have gone bankrupt. At the same time, were it not for Catmull's vision, implemented through his penchant 
for assembling technical talent to pursue cutting-edge projects, Pixar's company-saving and world-changing hit - Toy Story - would never have happened.

In a 2008 Harvard Business Review article, Catmull describes his management style - his preference for openness, equality, freedom, and the constant testing of assumptions - as an inheritance of his formative years in academia and research. Transposed to the world of commercial filmmaking, these academic practices and values almost killed Pixar. Having survived, however, the company's unconventional practices have had far-reaching impact in multiple domains: in animated filmmaking, obviously, but also in management studies, where Catmull's 2014 book, Creativity, Inc., has become a staple in corporate seminars and MBA classrooms, and where management scholars study Pixar's approach to innovation (Mannucci 2017). Even computer science has been affected; computer animation groups are de rigueur in any serious CS department. Catmull is known and respected in Hollywood, at Harvard Business School, and at SIGGRAPH - evidence of true amphibiousness.

\section{Case 2: Jacqueline Novogratz and the invention of nonprofit venture capital}

Jacqueline Novogratz was born to be a philanthropist. Her religious upbringing imbued her with a sense of responsibility to her fellow beings and a desire to make a difference in the world. Yet her family was firmly middle class; she didn't have financial wherewithal to instantly enter the philanthropic world as a donor. She resolved to educate herself, then look for opportunities to apply her knowledge and idealism to the world's toughest problems. She paid her way through the University of Virginia, graduating in 1983 with a degree in international relations and a bias for meaningful, service-oriented work. 
At this point, her trajectory took an unexpected turn. Lacking any concrete job prospects in the public sector, she added her resume to the stacks for international relations and economics grads in the university placement office. Unexpectedly, she was invited to interview for a job with Chase Manhattan Bank. Her account of the interview is comical (Novogratz 2009:5-6). The recruiter's first question was, "Tell me why you want to be a banker." Novogratz told the truth: "I don't want to be a banker. I want to change the world." The recruiter was somehow able to convince her that international banking would allow her to do just that. Thus began her intense training in international lending, coupled with extended visits to financial centers in the third world. Since that time, Novogratz has described herself as "an accidental banker" (PBS 2016).

If working as an international banker schooled her in the fundamental tools of capitalism, traveling the world acquainted her with the plight of the poor. After three years with Chase $-\mathrm{a}$ time she describes as "a stunning, privileged education" (Novogratz 2009:7) - she approached her boss with a novel idea. She had spent many months in Brazil, analyzing debt write-offs during the week and connecting with people in the city's favelas on weekends (Novogratz 2009:8):

The bank doors were closed to the poor and working class. Because the commercial banks were writing off millions in bad debts to the richest sectors of society, they were in no mood to try lending to the poorest. I suggested to my boss that an experiment, even a small one, to lend to Brazil's working class might actually provide better results than lending to the rich. He patted me on the head and reminded me of the poor's lack of collateral, the high transaction costs of making small loans, and the culture of poverty, which would result in no one repaying - insinuating that I was naïve and misguided. The conversation went from bad to worse. I disagreed with him on the culture of poverty and repeated my idea for an experiment. He told me the point was moot and that I should think about how and if I wanted to pursue my long-term career goals at Chase.

Novogratz describes this conversation as a defining moment in her career; it also illustrates many of the core elements of amphibiousness: the naivete, the clash between the fundamental values of different domains, and the incomprehensibility of traditional practices when imagined in a 
radically different context. After this conversation, Novogratz began looking for a way to take the tools she had mastered as a banker and apply them to helping the world's poor. Her next job was with the United Nations Childrens' Fund, which took her to Africa to help grow microfinance organizations that would lend to women entrepreneurs. The year was 1986; Novogratz recollects that "the big argument [in microfinance] was whether it was ethical to charge any interest at all, and I was one of those who believed that we should charge interest" (Javetski 2009). Her work led to an expanding range of opportunities, including stints with the World Bank and projects in various African countries. She saw so many failed philanthropic projects that she began an earnest search for a way to help the poor grow their own businesses rather than live off the unpredictable generosity of others.

Her quest took her from the microfinance organization she had helped found in Rwanda to one of the world's bastions of entrepreneurship: the Graduate School of Business at Stanford, where she earned an MBA. Reflecting on her time at Stanford, Novogratz (2009:121) says that her professors and fellow students were "comfortable speaking about power and money. Love and dignity, on the other hand, were words people were often embarrassed to say aloud, or so it felt. There had to be a way to combine the power, rigor, and discipline of the marketplace with the compassion I'd seen in so many other programs aimed at the very poor."

Novogratz's zig-zag path between traditional capitalism and third-world development continued after her graduation from Stanford in 1991. She accepted a fellowship at the Rockefeller Foundation, a role from which she gained a much deeper understanding of what might be termed "Big Philanthropy." Her travels took her all over the world again, yet she was growing dissatisfied with the workings of traditional philanthropy: 
At the end of 1999, I was sitting with the new president of the Rockefeller Foundation, Sir Gordon Conway, in his $22^{\text {nd }}$-floor office overlooking Manhattan, sharing my frustrations about traditional philanthropy, remarking that it often lacked clear measures and accountability and seemed at times more focused on making donors feel good than on effecting change. The world needed a new kind of institution, I said, one built on the best lessons and precepts of philanthropy but also utilizing business approaches and concepts ... one that would amass philanthropic money, have the flexibility to make grants or investments in both nonprofit and for-profit organizations, and take a few big bets on enterprises that delivered critical services to the poor, all to ensure that lowincome communities could actually be part of the solution. We would build more transparency and accountability into the work at all levels and treat the poor as customers with a real voice, not as passive recipients of charity (Novogratz 2009:213-14).

Novogratz realized her vision in 2001 with the founding of the Acumen Fund. Acumen is an odd mix of a charity and a traditional investment fund - a nonprofit venture capital fund whose goal is to use entrepreneurial approaches to address global poverty. Its stated aim is to demonstrate that "small amounts of philanthropic capital, combined with large doses of business acumen, can build thriving enterprises that serve vast numbers of the poor" (Ebrahim and Rangan 2011:1).

The new approach taken at Acumen involved raising charitable funds from individuals, foundations, and corporations, which in turn would be invested as equity or debt in enterprises serving bottom-of-the-pyramid markets. The enterprises could be nonprofit organizations with an earned-income revenue model or for-profit businesses. The target organizations had to be focused on delivering services to the poor in one of five areas: water, healthcare, housing, energy, or agriculture. Novogratz' experience at Stanford taught her the wisdom of the venture capital model, in which investors not only offer financial backing but also managerial know how and experience in business planning, strategy, performance management, and executive training. Such efforts at capacity building, as they have long been called in the international development world, were almost unheard of in organizations that served disadvantaged populations. Acumen believed that these services were essential to creating viable enterprises that could eventually stand on their own. Acumen's typical financial investment would involve a commitment of five 
to seven years; by contrast, the more traditional investments of philanthropic grant makers are from one to three years and venture capital firms bankroll startups for three to four years: “Our investment style was focused on what we termed patient capital — not traditional charity, not traditional business investment, but something in-between. Patient capital is money invested over a longer period of time with the acknowledgement that returns might be below market, but with a range of management support services to nurture the company to liftoff and beyond" (Novogratz 2009: 229).

Novogratz' amphibiousness enabled her to borrow investment criteria from realms that had little prior contact with one another. One criterion was the potential for significant social impact. Acumen invests with the purpose of increasing or upgrading the outputs of enterprises. A second criterion was the potential for an organization to reach financial sustainability within a sevenyear period. A third criterion was the potential to achieve scale, defined as reaching approximately one million users within seven years. One of its early investments were in the Aravind Eye Hospital in India, which has become a pioneer in the provision of eve surgery throughout India (Rangan, 2009). The hospital's R\&D arm designed and manufactured intraocular lenses (used in cataract surgery) for less than $\$ 10$ (the cost at the time was $\$ 140$ per lens). Another investment was in A-to-Z Textile Mills, a Tanzanian company that manufactures long-lasting insecticide-treated antimalarial bed nets. Within seven years, A-to-Z became one of the largest employers in Tanzania, hiring more than 7,000 people and producing 19 million bed nets per year.

By bringing business acumen to the realm of international development, Acumen has built a new organizational model and disseminated entrepreneurial ideas to the challenge of alleviating poverty. To promote lessons from its portfolio of investments, Acumen uses various means of 
communication. It distributes regular email newsletters, actively engages with a half million followers via Twitter and Facebook, and publishes a blog to broadcast activities, partnerships, and lessons. Acumen also offers a fellowship program for young professionals, as well as free online courses and volunteering opportunities to share its distinctive vision. One course, Storytelling for Change, teaches participants how to use powerful stories to connect with audiences and change conversations. Acumen's board of directors reflects it recombinatorial model, drawing people from the worlds of philanthropy, international aid, private equity, venture capital, and leading foundations.

Acumen's efforts have rebounded back into the worlds of international development and venture philanthropy. So-called "impact investing" was largely unheard of in 2001 when Acumen was founded but has since become a common topic of discussion (Brest, Gilson, and Wolfson, 2016). Such forms of investing, in either nonprofits or socially-minded for-profit ventures, are now typical of such firms as Bridges Ventures, the Omidyar Network, and the Gates Foundation. The recent move toward limited liability corporations (LLCs) in the philanthropic world in part reflects a desire to be able to invest in both nonprofit and for-profit social-purpose entities. Capacity building in the form of organizational training and upgrading has also become much more common in both the philanthropy and international development worlds. In short, what started out as Jacqueline Novogratz' oxymoronic vision - a nonprofit venture fund, designed to serve the global poor - has reverberated back into the worlds of philanthropy and foreign aid, as well as parts of the financial community. As Novogratz puts it,

When we started in 2000,2001 , it was a pretty uncrowded field. We were pretty much one of the only - well, maybe the only player at the very beginning that was using philanthropic money and investing equity in loans in for-profit companies. Now, it's a crowded field. Now there are other players who are coming in under the rubric of venture philanthropy or social-impact investing — you know, all across. (Javetski 2009) 


\section{Case 3: Carlos Santana and the Latin rock revolution}

A skinny Mexican immigrant playing blues licks on the streets of 1960s San Francisco may seem an unlikely musical pioneer. That immigrant was Carlos Santana, who learned the violin at age five and the guitar at age eight. He grew up in Mexico at the confluence of two unrelated musical worlds: the Latin music of his parents (his father was a mariachi musician), with its Afro-Cuban rhythms and extensive use of horns and percussion; and the guitar-driven, blues-based world of rock-n-roll, popular among Mexican teens. In the words of Tufts University anthropologist Deborah Pacini Hernandez (2010: 1-2), “Santana filtered [Latin music's] Spanish Caribbean sensibilities through his own deep knowledge of U.S. rock, which he had become familiar with not in the United States but in his Mexican homeland, where young people had embraced rock since the 1950s."

Santana's family moved to San Francisco in the late 1950s; Carlos graduated from Mission High School in 1965 . Both the place and the time were musically unique. San Francisco in the 1960s was a laboratory of rock experimentation, spawning musical innovators such as Jefferson Airplane, the Grateful Dead, and Janis Joplin. Skipping college, Santana began gigging with a group he called the Santana Blues Band. Santana's deep knowledge of and appreciation for Latin music was reflected in both the composition of the band, which included Latin percussionists playing timbales and congas, and the songs that the band wrote and covered.

Crucial in the development of the band's sound was the fact that they shared a house and swapped records, exposing the band members to a wide variety of musical styles. As drummer Mike Shrieve recalls, "When I moved in with the guys in the band, it was really fascinating to me because everybody had their own records. Music was going all the time but everyone was 
sharing" (Contreras 2016). Santana adds, "Everyone was bringing their own love affair or what they liked, you know. Michael Shrieve was bringing Coltrane and Miles and Elvin Jones. [Percussionists] Carabello and Chipito were bringing Tito Puente, Eddie Palmieri, and Ray Barretto. For me, it was just basically blues. I would listen to John Lee Hooker, Lightnin’ Hopkins, and Jimmy Reed." The confluence of these musical influences created the opportunity for novel recombinations, one of which launched an entirely new genre - Latin Rock - that has had lasting influence on both traditional Latin music and mainstream rock.

Santana describes becoming interested in melding the Caribbean music he was raised on with the hard-driving blues he had grown to love. In his words, "I was getting more and more fascinated with how to cross pollinate Tito Puente with B.B. King” (Contreras 2016) - an unlikely combination, to be sure. Tito Puente was a New York-born band leader of Puerto Rican descent whose music was popular in the Latino world but had never crossed over to non-Latin listeners. By the same token, rock and blues had never made use of the textures and rhythms of AfroCuban percussion. A prime example of Santana's unique, genre-busting sound is his reinvention of a Puente composition, “Oye Como Va!” Santana substituted blues-derived guitar licks and Hammond B3 organ punches for Puente's horns, but kept the underlying cha-cha rhythm. Pacini Hernandez (2010:2) explains, "Ironically, it was an immigrant Mexican rocker who, in pioneering the subgenre of Latin rock, introduced the U.S.-born Puente's Afro-Cuban dance music to mainstream U.S. rock audiences."

Santana's influence extended beyond the U.S., of course. His version of "Oye Como Va!" hit number 13 on Billboard's Top 100 chart and, in the process, introduced Latin music to a worldwide fan base. In 2000, National Public Radio’s All Things Considered included “Oye Como Va!" among the 100 most important American songs of the $20^{\text {th }}$ century, "a decision based 
on its profound influence on musical developments in the United States" (Pacini Hernandez 2010: 2). In announcing the award, NPR quoted Cesar Rosas, Mexican-born lead guitarist for the Latin rock group, Los Lobos, regarding the impact of Santana's music: "Carlos Santana created a new kind of music. ... He fused together two awesome elements, the most romantic two elements ever: one being rock-n-roll, which is very romantic, electric guitar, blues-based; and then he also picked Latin music, which is extremely romantic. And when he fused those two together, it just exploded" (Welna 2000).

Carlos Santana has since recorded with artists in a variety of styles, including critically acclaimed albums of mainstream jazz. Indeed, he might be called "multiphibious," due to his facility with bending and crossing musical genres. Santana explains his genius matter-of-factly: "I just rely on a portfolio or rolodex in my brain" (Contreras 2016). Felix Contreras, host of NPR's alt.latino radio show, credits Santana with setting in motion a "magical process of transformation and creation in which the band combined unrelated styles and genres to create a sound that is still popular 50 years later."

\section{Case 4: Victoria Hale and the struggle to create a nonprofit pharmaceutical firm}

Victoria Hale received her Bachelor of Science in Pharmacy from the University of Maryland (Baltimore) in 1983. After two years as a clinical pharmacist at the Johns Hopkins Medical Institutions, she continued her studies at the University of California at San Francisco, earning a Ph.D. in pharmaceutical chemistry in 1990. Rather than remain in academia, she took a job with the U.S. Food and Drug Administration (FDA) as a reviewer in the Center for Drug Evaluation and Research. During her five-year tenure there, she witnessed what happens to medicines for unprofitable markets. A pharmaceutical firm was developing a new drug for two promising indications. One was a potential blockbuster; the other was an orphan disease, a label given to 
diseases that affect fewer than 200,000 people worldwide. The firm's executives decided to focus on the blockbuster and abandon the orphan disease because it distracted the company from the more profitable indication. In addition, as a member of the FDA's pilot drug evaluation staff, Dr. Hale became familiar with compounds that were seeking approval for a single disease but could be extended to cure other diseases. This sparked an idea: If an organization could obtain the rights to these half-developed compounds and tweak them to solve neglected diseases, it would be a win-win (Mair, 2005).

From the FDA, Dr. Hale moved to Genentech, one of the earliest and most successful biotech companies. Genentech had close ties with UCSF and was focused on developing new-to-theworld medicines, but not on products for diseases in the developing world. Although Dr. Hale's career moved quickly at Genentech, she could not escape the idea of creating an alternative kind of pharmaceutical company. After three years, she left to devote full attention to a unique new venture that would become the Institute for One World Health (IOWH).

Dr. Hale's time at the FDA had given her a first-hand understanding of the drug approval process. Her experience at Genentech had exposed her to the commercial side of bringing new drugs to market, including the bias toward products designed to treat diseases in the Global North. Dr. Hale began developing the moral view that life-saving drugs should be available for everyone who needs them. As she told the Stanford Social Innovation Review in 2007,

When there are blockbuster opportunities that generate significant revenues, the pharmaceutical industry runs to them. But when there are opportunities that affect very, very poor people, the industry doesn't respond very well. That was the position that global infectious diseases were in. So the question was simple: If the barrier to developing drugs for these medicines is the profitability requirement, then it should be possible to develop these medicines within a pharmaceutical company that doesn't have that profitability requirement (Nee 2007). 
In pursuing her vision of a non-profit pharmaceutical company, she was swimming against the tide. IOWH was conceived as a nonprofit company in an industry that has long been one of the most profitable of global enterprises. Potential investors reacted with the confusion that often meets amphibious entrepreneurs:

Research and development costs for new medicines are in the tens of millions of dollars. The traditional sources of funding that would lead to a for-profit entity-venture capitaljust didn't work. We couldn't even get two minutes in front of a venture capitalist. . . We were an oxymoron, something that people would laugh at and say, "Oh, that'll never work" (Nee 2007).

Dr. Hale exhibited the naïveté typical of amphibious entrepreneurs: "I talked to lots of people about my idea in the beginning — and I didn't listen to them, or I wouldn't be here. I talked to one former executive from a big pharmaceutical company and he said, 'You won't be successful. It takes at least 10,000 people to make a drug"” (Hayden 2007). Undaunted, Dr. Hale officially launched the non-profit IOWH with her husband, Ahvie Herskovitz, in July 2000. IOWH's mission was to focus on neglected tropical diseases (NTDs), a designation that includes a variety of parasitic illnesses such as trypanosomiasis (sleeping sickness), leishmaniasis (black fever), and Chagas disease, all common to the tropics. That same year, the World Health Organization had designated these as the three main neglected diseases, estimating that less than 10 percent of global spending on health research was devoted to diseases or conditions that account for 90 percent of the global disease burden. Notably, of the 1,391 new drugs approved in Europe and the U.S. between 1975 and 1999, only 16 were indicated for tropical diseases (Mair, 2005). Indeed, only four compounds for tropical diseases were developed by commercial pharmaceutical companies over this time period.

Drawing on her experience at Genentech and the FDA, Dr. Hale designed a new business model to tackle the challenge of developing medicines for NTDs. IOWH could not realistically take a 
drug from research to production; it had to focus on the phases of the drug-development process it could affect. As Dr. Hale explained in a 2007 interview,

We're in downtown San Francisco, so we don't have a factory and we don't have any laboratories. We partner to do our laboratory work and our manufacturing. We do hold on to the 'D,' the development part, where you're doing animal studies and clinical trials. But for the ' $\mathrm{R}$,' we really do need to partner with the inventors of the technology (Nee 2007).

IOWH raised funds through traditional philanthropic channels and found promising compounds through contacts with the pharmaceutical industry and research universities. By seeking compounds that incumbent firms had chosen not to develop, IOWH would continue the research process, eventually leading to preclinical and clinical tests and regulatory approval. Then it would find partners to handle the manufacturing and distribution of the drugs in underserved, third-world markets. IOWH obtained royalty-free licenses and patent donations for compounds from smaller biotech companies and several universities, as well as a few donations of compounds that large pharma companies.

Although the idea of a nonprofit pharmaceutical company was unusual, Dr. Hale was able to attract donors. For example, the Gates Foundation provided her with seed money and became a major partner. The WHO alerted IOWH to an off-patent antibiotic for the treatment of visceral leishmaniasis (black fever), which was killing 200,000 people per year and afflicting many more. This antibiotic (paromomycin) had been donated to the WHO by an Italian drug company, which held the license. The WHO had run out of funding for its clinical trials but was keen to partner with IOWH. In addition to black fever, sleeping sickness, and river blindness, IOWH also received licenses for a promising new drug against Chagas disease donated by Celera Genomics. Licenses and donations from academia followed, with Yale University and the University of 
Washington providing royalty-free licenses to compounds that might also be useful in treating Chagas disease. The University of California Santa Barbara donated a patent that could lead to a potential treatment for schistosomiasis.

As has been mentioned, IOWH operated differently from large pharmaceutical firms and even small biotech companies in that its goal was to develop drugs for which no significant market existed. But it also differed from international public health organizations in that IOWH had the capability to run clinical trials and draw on the expertise in drug development that had previously been controlled only by private sector companies. IOWH pioneered a model of private-publicnonprofit partnerships that pursued drug development projects for single diseases.

In 2006, IOWH secured approval from the Indian government to use intramuscular injections of paromomycin to treat black fever. The antibiotic had been in use for more than 60 years but was off patent. With $\$ 17$ million in funding from the Gates Foundation, IOWH was able to establish paromomycin's efficacy as a low-cost treatment for black fever. Dr. Hale referred to this approval as "a crowning moment. It was the proof of concept that a nonprofit pharmaceutical company could get a drug approved" (Hayden 2007).

IOWH began focusing on other diseases - notably malaria, Chagas' disease, and secretory diarrhea - but sustainability became a concern. IOWH envisioned making medicines affordable by selling their drugs in two-tiered pricing schedules: a very low price for public health agencies and a market rate for commercial pharmacies. Such a scheme was hard to implement, however, partly because large pharmaceutical companies began to donate drugs for use in the third world. For example, pharma-company drug donations to USAID's NTD program grew tenfold in the past decade, from a value of $\$ 404$ million in 2007 to $\$ 4.5$ billion in 2016 (USAID 2017). 
Although IOWH was the first nonprofit pharmaceutical company in the U.S., it did not survive as an independent entity. In 2011, IOWH became part of PATH, an international nonprofit organization focused on improving the health of disadvantaged populations worldwide. PATH's proven access to philanthropic funding enabled the work envisioned by Dr. Hale to continue, but IOWH's unique business model was subsumed into that of a traditional (albeit successful) NGO.

When Dr. Hale stepped down as CEO of IOWH in 2007, she described her continuing vision for solving neglected diseases:

I do believe that there are some diseases that are best treated without there being a requirement for a return on investment or even a recouping of the $\mathrm{R} \& \mathrm{D}$ costs. The technology's there, the need is there, the passionate expertise is there. It just needs to be housed in something that is a for-profit/not-for-profit hybrid, whatever you want to call it. OneWorld Health's model should have a second generation that has evolved (Nee 2007). A dominant model for these second-generation "for-profit/not-for-profit hybrid" organizations has yet to emerge. Innovative experiments abound, including the Genomics Institute of the Novartis Research Foundation, a nonprofit organization founded in 1999 by the Swiss pharma giant Novartis, the U.S. Government, and other foundations. The Institute straddles the world of academic, nonprofit, and commercial science. So-called Product Development Partnerships are another organizational form that involves collaboration among philanthropies, governments, and corporations "to create health solutions for diseases of the poor in developing countries" (Topal 2014). Data collected by the World Health Organization, however, show that between 2007 and 2015, investments in PDPs for R\&D on neglected diseases have declined from $\$ 540$ million to \$450 million (World Health Organization 2017).

In short, the IOWH resulted from the efforts of an amphibious entrepreneur to solve a complex problem: how to develop treatments for neglected tropical diseases in the absence of market incentives to do so. The result was a radically new type of organization, the nonprofit 
pharmaceutical corporation. Although it successfully brought a treatment for black fever to market in India, Dr. Hale's innovation did not survive. Rather, IOWH was incorporated into a more traditional nonprofit organization, while at the same time, for-profit pharma companies stepped up their donations of drugs to treat neglected diseases.

\section{DISCUSSION AND IMPLICATIONS}

The foregoing cases illustrate the basic mechanism of amphibious entrepreneurship: the transposition of ideas, practices, and values from one social domain to another in which they are essentially unknown. In each case, the transposition was effected by an individual whose focus was on solving a problem: how to create an animated feature film digitally, how to ameliorate third-world poverty, how to integrate two disparate musical styles, or how to develop drugs for populations that cannot afford to pay for them. In their efforts to solve the problem, these individuals drew on approaches and techniques that were natural or instinctive to them yet radically different from the taken-for-granted approaches in the domains where the problem resided. Ed Catmull brought organizing assumptions and a researcher's ethos from academia to (of all places) Hollywood. Jacqueline Novogratz could not suppress her international banker's perspective when confronted with the challenges of poverty. Carlos Santana inevitably heard and played the blues through a Latin-tinged sensibility. Victoria Hale carried her knowledge of overlooked pharmaceutical compounds to the arena of neglected tropical diseases. In the first three cases, the entrepreneurs' credibility and status in their domains of origin, coupled with notable achievements in new domains, concatenated in unforeseen ways to trigger changes beyond the scope of the original problem to be solved. In the fourth case, established patterns of activity were ultimately insurmountable; the distinctive elements of Dr. Hale's for-/non-profit 
hybrid were absorbed back into the commercial interests of the pharmaceutical industry and the philanthropic interests of a successful NGO.

In the remainder of this chapter, we move from the specifics of these cases to broader examination of the role of amphibious entrepreneurs in creating interstices between previously separate social domains, and how this role differs from other boundary-spanning roles known to be associated with the emergence of novelty. We also offer our perspective on potentially promising directions for future research related to amphibiousness.

\section{The creation of interstitial spaces}

A crucial way in which amphibious entrepreneurs generate novelty is through the creation of new border spaces between formerly separate lines of activity and thought. We call such spaces interstices. Scholars have long recognized the fertility of such locations. Michael Mann (1986; 2012), in his magisterial History of Social Power, argues that interstices are the spaces at the margins of previously dominant ideologies where transformational power leaps happen. These power leaps remade civilizations and catapulted social upheavals that overthrew established regimes. Physical and biological scientists view interstices as critical components of ecosystems (e.g., the confluence of two rivers, or of a river and the ocean, that creates the organically rich conditions that foster biodiversity).

In the world of culture, an interstice is a space where genres may be crossed and new visions formed. The performance artist Lori Anderson sings, reads poetry, dances, and tries out odd instruments at her concerts. The polymathic cellist Yo-Yo Ma is an interstitial bridge between classic and bluegrass music, and he also plays with modern jazz and traditional Silk Road musicians. Amphibious entrepreneurs create interstitial organizations that meld influences from 
different contexts; consequently, they inhabit gradated environments that are partly one thing and partly another. The advantage of such an interstitial position is that ideas, practices, and (importantly) values can be exchanged and boundary-crossing ties formed. Social resources from one domain move to another with unusual repercussions. Formerly separate communities can be brought together, which is particularly consequential when entirely new meanings emerge out of such contexts.

\section{Comparison to other boundary-spanning roles}

Scholars have identified numerous roles that facilitate the confluence of ideas, practices, and values across social boundaries. Table 1 compares and contrasts a few of these roles.

\section{[ INSERT TABLE 1 HERE ]}

Boundary spanners. Tushman and Scanlan's (1981: 292) original characterization of the boundary spanning role described an individual adept at "obtaining information from outside units and disseminating this information to internal users." Their focus was on information transfer: knowledge from sources external to the organization was rendered comprehensible and made available to internal constituents. Implicit in this definition is the boundary spanner's position as a member of an organization (or organizational unit) who translates knowledge from outside the organization (or unit) for the benefit of the organization. Tushman and Scanlan's work is central to a rich and extensive literature on knowledge management and innovation.

The key similarity between boundary spanners and amphibious entrepreneurs is the notion of transporting knowledge between domains. Indeed, recent studies build on March's (1991) observation that flows of human capital into and out of organizations bring opportunities for the transfer of novel ideas and practices (Godart, Shipilov \& Claes 2013). Thus, new hires have 
some amphibious qualities in that they bring assumptions and perspectives from other contexts to their new employer and can (in some cases) maintain contact with their prior context, facilitating ongoing exchange. The scope of such effects, however, is organizational. In contrast, amphibious entrepreneurs operate as bridges between distinct domains of the social landscape, with the possibility of larger-scale novelty (even when such novelty was not their original intent).

Mavericks. Patriotta and Hirsch (2016) describe an intriguing role in their exploration of innovation in art worlds. They identify certain individuals, labeled "mavericks," who occupy positions at the periphery of existing fields and are thus able to flout convention and introduce ideas and values that do not conform to established norms (Phillips \& Zuckerman 2001). The maverick and the amphibian are similar in their nonconformance, with key differences in scope and intentionality. The maverick's challenges to the existing order are calculated and deliberate; she seeks to change prevailing institutional arrangements and does so within a defined institutional field (Jones et al., 2016). The amphibian, on the other hand, lacks the antagonism that characterizes the maverick; her countercultural intrusions result from immersion in one set of assumptions and the naïve, unquestioned (indeed, almost inevitable) application of these assumptions in a different domain.

Brokers. Brokers are typically individuals or select organizations located in particularly advantageous structural positions. Brokers span holes in the social structure and are thus able to control the flow of information or resources between separate parties. A broker then reaps benefits from uniting two or more disconnected parties (Burt 1992). Such gains can be financial, reputational, or political. Brokers bring disparate parties together to derive benefits. As such, brokerage is based on the desire to use network position as a basis to garner different forms of profit. In an important respect, brokerage is an import-export business (Burt 2004). Brokers can 
excel at conflict resolution in that they can communicate misunderstandings, bring awareness to problems that both parties face, and build mutual insight. Brokers can transfer best practices from one domain to another. And brokers can draw analogies that others might typically ignore, thus overcoming the usual refrain of "our situation is different." But brokerage rarely staples together principles and practices from disparate domains or generates spillovers that are advantageous to many others; nor does brokerage typically create new fields.

In contrast, amphibians provide services that bridge worlds that were formerly separate. As with brokerage, older ideas take on a new life when used in a different setting. But this is not merely import-export, as it modifies the new structure. Status earned in one domain is converted into legitimacy in another, helping the new social category survive (Khaire 2010). In contrast, when skills from one domain are moved to another, the repercussions are impossible to predict. By synthesizing or recombining diverse ideas and elements from different groups, brokers can take disparate contributions and create new uses for them that others build on (Long Lingo \& O’Mahony 2010). Such efforts always create tension because the transfer of ideas is not a simple plug and play but has unexpected, ramifying effects.

In our examples above, formerly separate communities are brought together in a consequential fashion as new meanings and new activities emerge out of such contacts. When a skill or purpose is used in a different context, its functionality is redefined. Not only does the familiar thing take on a different meaning in a new context, but also this new meaning is carried back into the amphibian's home domain. Amphibians not only build a bridge, they widen the bridge and create a flow of traffic between different domains in ways that transform participants on both sides of the bridge. Such actions result in not only an old idea doing a new job, but the idea itself being transformed so that the topology of possibilities is altered in the two domains. Thus, although the 
success rate of brokers is likely much higher than that of amphibians, the consequences of successful amphibiousness are potentially more profound.

\section{Directions for future research}

We have argued that amphibious entrepreneurs move ideas and practices from a domain where they are familiar into another where they are alien and not initially recognized. Such boundary crossing is charged with generative potential. To be sure, almost all novelty is "a recombination of conceptual and physical materials that were previously in existence" (Nelson \& Winter 1982: 130). We argue, however, that it matters a great deal whether recombination occurs on a familiar terrain (e.g., an organization in the same or adjacent field or industry) or in a new or distant setting where the components are foreign. This traffic across social worlds can create new social spaces and repurpose existing cultural practices in unfamiliar circumstances, resulting in marked departures from past practice.

Such boundary crossings typically involve considerable skill (Fligstein 1997). This raises the question of who is most likely to engage successfully in such transpositions? Ambiguity of action and speech are needed, as multi-vocal actors are able to hold positions across multiple relations with variable meanings. This suggests that high-status individuals may be better able to maintain a foot in two worlds, as they are better equipped to survive the antagonism they will likely experience. In the early days of the biotech industry, for example, it was prestigious scientists at elite universities who were able to create the first-generation of science-based companies by using their research accomplishments to secure financing from young venture capital firms. But none of these "scientists in business to do science" quit their academic day jobs (Powell \& Sandholtz, 2012b). The ability to move in two different social worlds was enabled by their lofty standing in one established sphere. Is accomplishment in one realm a 
necessary requirement for amphibious entrepreneurs? Or is it possible for upstarts, without firm footing in any domain, to simultaneously tack between realms, importing practices from one sphere into another with transformative consequences? The case of Carlos Santana suggests that low-status individuals from multi-ethnic backgrounds may be capable of toggling between identities without experiencing ostracism. Future research could examine the relative status of amphibians in different domains, focusing on whether the ability to frame arguments in multiple registers is dependent on prior achievements in one domain (Stark 2009).

A related topic for further pursuit is the nature of cascading effects. What is the best way to analyze the conditions under which effects from one domain spill promiscuously into others? Is this a general process or always context-specific? How might such processes be studied empirically? In his research on Renaissance Florence, John Padgett has documented how the same actors' actions in different contexts can have remarkably divergent consequences (Padgett 2012). His exceptionally detailed data on family, business, and political relations over two centuries show that some network transpositions are more consequential than others and are often context-dependent. How to measure these spillovers and shifts quantitatively remains a challenge, although research on tactical repertoires in social movement studies shows such work is feasible.

Relevant to the question of cascading effects is a more general examination of the temporal characteristics of amphibious entrepreneurship. At what point in the development of an idea, a technology, or a body of scientific findings does it become ripe for transposition to a distant domain by an amphibious entrepreneur? And when are such moves most likely to take root? Ed Catmull's career history suggests that computer-generated animation had to reach a certain level of sophistication before it could be successfully transposed to the world of Hollywood film 
making - and even when the technology was ready, Hollywood decision makers were dismissive. Computer graphics research was in its infancy in 1974, when Catmull received his Ph.D. He remained at the cutting edge of this research for the next 20 years, first in nonprofit research labs and then in for-profit firms, before the release of Toy Story in 1995. A similarly long gestation period characterized Jacqueline Novogratz's founding of Acumen in 2001, after unsuccessfully proposing the idea to her manager at Chase Manhattan Bank in 1986; he thought the idea was absurd. Unpacking how individual readiness and societal poisedness interact to enable amphibious action would make a considerable contribution to entrepreneurship research (cf. Johnson \& Powell 2017).

Finally, cultural sociologists have argued that there is an "art" to entrepreneurship (Peterson and Berger, 1971; Johnson, 2007). Much more than just assembling pre-existing elements, cultural entrepreneurship "extends to the moral, cultural, and social spheres as well" (Peterson and Berger, 1971: 103). Similarly, in her work on the founding of the Paris Opera in the 17th century, Johnson highlights the wide array of cultural elements involved in creating a new organizational form. Historical sociologists stress that time is lumpy, unpredictable, and discontinuous (Abbott 2001). Such a view alerts us, as Sewell (2005, p. 10) gracefully notes, "that the consequences of a given act are not intrinsic in the act but rather will depend on the nature of the social world within which it takes place." Temporal heterogeneity renders some actions - including efforts at organizational creation - incomprehensible or illegitimate at certain historical moments, yet comprehensible and legitimate at others. Explaining when and why new organizational forms emerge and persist calls for analysis of the relations between efforts at invention and the social worlds in which those efforts unfold. Such historically informed study is 
largely missing from organizational research on entrepreneurship, which creates ample opportunity to connect historical scholarship with entrepreneurship studies.

We began by asserting that social science is limited in its ability to explain novelty. Although we have not solved this limitation, we suggest a line of work on amphibiousness, which illuminates how new ideas emerge from connecting two distant social worlds. When these ideas concatenate and gain traction, they can reverberate back into their domains of origin with powerful transformative consequences. 


\section{REFERENCES}

Abbott, Andrew. 2001. Time Matters: On Theory and Method. Chicago: University of Chicago Press.

Baumer, Benjamin and Andrew Zimbalist. 2015. The Sabermetric Revolution: Assessing the Growth of Analytics in Baseball. Philadelphia, PA: University of Pennsylvania Press.

Black, Fischer and Myron Scholes. 1973. "The Pricing of Options and Corporate Liabilities," Journal of Political Economy 81(3): 637-654.

Brest, Paul, Ronald Gilson, \& Mark Wolfson. 2016. “How Investors Can (and Can’t) Create Social Value." Stanford Social Innovation Review. https://ssir.org/articles/entry/how_investors_can_and_cant_create_social_value

Burt, Ronald S. 1992. Structural Holes: The social structure of competition. Cambridge, MA: Harvard University Press.

Burt, Ronald S., 2004. "Structural Holes and Good Ideas." American Journal of Sociology 110(2): 349-99.

Catmull, Edwin E. 2008. "How Pixar Fosters Collective Creativity." Harvard Business Review (September).

Catmull, Edwin E. 2014. Creativity Inc.: Overcoming the unseen forces that stand in the way of true inspiration. New York: Random House.

Cohen, Michael. 2007. "Reading Dewey: Reflections on the Study of Routine," Organization Studies 28(5): 773-786.

Contreras, Felix. 2016. "Carlos Santana Breaks Down His Band's Trailblazing Sound." Originally broadcast on alt.latino radio program on April 14. Accessed July 26, 2017, at http://www.npr.org/sections/altlatino/2016/04/14/474201279/carlos-santana-breaksdown-his-bands-trailblazing-sound.

Ebrahim, Alnoor and V. Kasturi Rangan. 2011. "Acumen Fund: Measurement in Impact Investing (A)," HBS Case 9-310-001. Boston: Harvard Business School Publishing.

Fisher, Greg, Suresh Kotha, and Amrita Lahiri. 2016. "Changing with the Times: An integrated view of identity, legitimacy, and new venture life cycles." Academy of Management Review 41(3):383-409.

Fligstein, Neil. 1997. "Social Skill and Institutional Theory." American Behavioral Scientist 40 (4): 397-405.

Gilson, Ronald J., Charles F. Sabel, and Robert E. Scott. 2009. "Contracting for Innovation: Vertical Disintegration and Interfirm Collaboration." Columbia Law Review 109(3): 431502.

Godart, Frederic C., Andrew V. Shipilov, and Kim Claes. 2013. "Making the most of the revolving door: The impact of outward personnel mobility networks on organizational creativity." Organization Science 25(2): 377-400. 
Hayden, Erika C. 2007. "Straight Talk from Victoria Hale.” Nature Medicine 13(11): 1274.

Hiatt, Shon R., Wesley D. Sine, and Pamela S. Tolbert. 2009. "From Pabst to Pepsi: The Deinstitutionalization of Social Practices and the Creation of Entrepreneurial Opportunities." Administrative Science Quarterly 54 (4): 635-67.

Hollar, John. 2013. "Oral History of Edwin Catmull, 2013 Computer History Museum Fellow." Computer History Museum Oral History Collection.

http://www.computerhistory.org/collections/oralhistories.

Javetski, Bill. 2009. "The State of Philanthropy: A conversation with Acumen Fund's CEO." McKinsey Quarterly, March. Accessed at http://www.mckinsey.com/industries/socialsector/our-insights/the-state-of-philanthropy-a-conversation-with-acumen-funds-ceo.

Jones, Candace, Silviya Svejenova, Jesper Strandgaard Pedersen, and Barbara Townley. 2016. "Misfits, Mavericks and Mainstreams: Drivers of innovation in the creative industries." Organization Studies 37(6): 751-768

Johnson, Victoria. 2007. "What is Organizational Imprinting? Cultural Entrepreneurship in the Founding of the Paris Opera." American Journal of Sociology 113:97-127.

Johnson, Victoria, and Walter W. Powell. 2017. “Organizational Poisedness and the Transformation of Civic Order in Ninteenth-Century New York City." In Organizations, Civil Society, and the Roots of Development, edited by Naomi R. Lamoreaux and John Joseph Wallis, pp. 179-230. University Of Chicago Press.

Khaire, Mukti. 2009. "Young and No Money? Never Mind: The Material Impact of Social Resources on New Venture Growth.” Organization Science 21 (1): 168-85.

Lewis, Michael. 2003. Moneyball: The Art of Winning an Unfair Game. New York, NY: W.W. Norton and Company.

Long Lingo, Elizabeth, and Siobhan O’Mahony. 2010. "Nexus Work: Brokerage on Creative Projects.” Administrative Science Quarterly 55(1): 47-81.

Mair, Johanna. 2005. "A Mew Model for the Pharmaceutical Industry: Institute for One World Health.” IESE Business School Case 0-305-050, Barcelona, Spain.

Mann, Michael. 1986. The Sources of Social Power, Vol. 1. Cambridge, UK: Cambridge University Press.

Mannucci, Pier Vittorio. 2017. "Drawing Snow White and Animating Buzz Lightyear: Technological toolkit characteristics and creativity in cross-disciplinary teams." Organization Science 28(4): 711-28.

March, James G., 1991. "Exploration and exploitation in organizational learning." Organization Science 2(1): 71-87.

Mintz, Cliff. 2010. "Fostering Pharma R\&D." https://www.pharmaceuticalonline.com/doc/fostering-pharma-rd-0001

Mora, G. Cristina. 2014. "Cross-Field Effects and Ethnic Classification: The Institutionalization of Hispanic Pan-ethnicity, 1965 to 1990," American Sociological Review 79(2):183-210. 
Nee, Eric. 2007. "Fifteen Minutes with Victoria Hale: MacArthur 'genius' prize winner creates drugs for the developing world.” Stanford Social Innovation Review (Winter).

Nelson, Richard R., and Sidney G. Winter. 1982. An Evolutionary Theory of Economic Change. Cambridge, MA: Harvard Business School Press.

Novogratz, Jacqueline. 2009. The Blue Sweater: Bridging the gap between rich and poor in an interconnected world. New York: Macmillan.

Opazo, M. Pilar. 2016. Appetite for Innovation: Creativity and Change at El Bulli. New York: Columbia University Press.

PBS. 2016. "Brief but spectacular: Jacqueline Novogratz' take on dignity and the moral imagination.” PBS News Hour. Originally aired Dec 15. Accessed at https://www.pbs.org/newshour/brief/201429/jacqueline-novogratz.

Pacini Hernandez, Deborah. 2010. Oye Como Va!: Hybridity and Identity in Latino Popular Music. Philadelphia, PA: Temple University Press.

Padgett, John F., and Paul D. McLean. 2006. "Organizational Invention and Elite Transformation: The Birth of Partnership Systems in Renaissance Florence." American Journal of Sociology 111 (5): 1463-1568.

Padgett, John F. and Walter W. Powell. 2012. "The problem of emergence.” In J. F. Padgett \& W. W. Powell (eds.), The emergence of organizations and markets (1-32). Princeton, New Jersey: Princeton University Press.

Padgett, John F. 2012. "Transposition and Refunctionality: The Birth of Partnership Systems in Renaissance Florence.” In J. F. Padgett \& W. W. Powell (eds.), The emergence of organizations and markets (168-207). Princeton, New Jersey: Princeton University Press.

Patriotta, Gerardo and Paul M. Hirsch. 2016. "Mainstreaming Innovation in Art Worlds: Cooperative links, conventions and amphibious artists." Organization Studies 37(6): 867887.

Perren, Alisa. 2012. Indie, Inc.: Miramax and the transformation of Hollywood in the 1990s. Austin: University of Texas Press.

Peterson, R.A. and D.G. Berger. 1971. "Entrepreneurship in Organizations: Evidence from the Popular Music Industry.” Administrative Science Quarterly 16: 97-106.

Phillips, Damon J., and Ezra. W. Zuckerman. 2001. "Middle-status conformity: Theoretical restatement and empirical demonstration in two markets." American Journal of Sociology, 107(2): 379-429.

Powell, Walter W. and Kurt Sandholtz. 2012a. "Chance, Necessite, et Naivete: Ingredients to Create a New Organizational Form.” In J. F. Padgett \& W. W. Powell (eds.), The emergence of organizations and markets (370-433). Princeton, NJ: Princeton University Press. 
Powell, Walter W. and Kurt Sandholtz. 2012b. "Amphibious Entrepreneurs and the Emergence of Organizational Forms," Strategic Entrepreneurship Journal 6: 94-115.

Rangan, V. Kasturi. 2009. “Aravind Eye Hospital, Madurai, India: In Service for Sight,” HBS Case 593-098, Boston: Harvard Business School Publishing.

Sewell, William H., Jr. 2005. "Theory, History, and Social Science.” In Logics of History: Social Theory and Social Transformation, pp. 1-21. Chicago: University of Chicago Press.

Sine, Wesley D., Heather A. Haveman, and Pamela S. Tolbert. 2005. "Risky Business? Entrepreneurship in the New Independent-Power Sector." Administrative Science Quarterly 50 (3): 200-232.

Slusser, Susan. 2017. "Moneyball at 20: Inside Billy Beane's legacy after two decades running the A's." San Francisco Chronicle. August 25: A 11.

Snow, David A., E. Burke Rochford, Jr., Steven K. Worden, Robert D. Benford. 1986. "Frame Alignment Processes, Micromobilization, and Movement Participation." American Sociological Review 51(4): 464-81.

Stark, David. 2009. The Sense of Dissonance: Accounts of worth in economic life. Princeton, NJ: Princeton University Press.

Svejenova, Silviya, C. Mazza, and M. Planellas. 2007. "Cooking Up Change in Haute Cuisine: Ferran Adrià as Institutional Entrepreneur.” Journal of Organizational Behavior 28(5): 539-61.

Topal, Claire. 2014. "The Value of Product Development Partnerships: An interview with Rob Lin." The National Bureau of Asian Research. August 11. http://www.nbr.org/downloads/pdfs/cha/Lin interview 081114.pdf. Accessed 28 Sept 2017.

Tushman, Michael L., and Thomas J. Scanlan. 1981. "Boundary Spanning Individuals: Their role in information transfer and their antecedents." Academy of Management Journal 24(2):289-305.

USAID. 2017. "Drug Donation Partnerships.” Neglected Tropical Diseases Program. https://www.neglecteddiseases.gov/about/drug-donation-partnership. Accessed 29 Sept 2017.

Vedres, Balázs, and David Stark. 2010. "Structural Folds: Generative Disruption in Overlapping Groups.” American Journal of Sociology 115 (4): 1150-90.

Wang, Dan J. and Sarah Soule. 2012. "Social Movement Organizational Collaboration: Networks of Learning and the Diffusion of Protest Tactics, 1960-1995." American Journal of Sociology 117(6): 1674-1722.

Wang, Dan .J. and Sarah A. Soule. 2016. "Tactical innovation in social movements: The effects of peripheral and multi-issue protest." American Sociological Review 81(3): 517-48.

Wang, Dan J. and Alessandro Piazza. 2016. "The Use of Disruptive Tactics in Protest as a TradeOff: The Role of Social Movement Claims," Social Forces 94(4):1675-1710. 
Welna, David. 2000. NPR 100, broadcast September 25.

World Health Organization. 2017. "Distribution of R\&D funding flows for neglected diseases, by source and type of funding." World Health Organization. July. http://www.who.int/researchobservatory/monitoring/inputs/neglected_diseases_source/en/. Access 28 Sept 2017. 


\section{TABLES AND FIGURES}

Table 1: Characteristics of Amphibians vs. Other Novelty-Generating Roles

\begin{tabular}{llll}
\hline Role & Structural position & Scope of novelty & Mechanism \\
\hline $\begin{array}{l}\text { Boundary spanner } \\
\begin{array}{l}\text { (Tushman \& Scanlan } \\
\text { 1981) }\end{array}\end{array}$ & $\begin{array}{l}\text { Interface between organization } \\
\text { and environment }\end{array}$ & Within an organization & Translation \\
$\begin{array}{l}\text { Maverick } \\
\text { (Patriotta \& Hirsch 2016) }\end{array}$ & $\begin{array}{l}\text { Peripheral member of } \\
\text { existing domain }\end{array}$ & $\begin{array}{l}\text { Within a domain } \\
\text { (e.g., the art world) }\end{array}$ & Iconoclasm \\
$\begin{array}{l}\text { Broker } \\
\text { (Burt 1992) }\end{array}$ & $\begin{array}{l}\text { Bridging tie between nodes } \\
\text { in a social network }\end{array}$ & $\begin{array}{l}\text { Between organizations or } \\
\text { domains }\end{array}$ & Arbitrage \\
$\begin{array}{l}\text { Amphibious } \\
\text { entrepreneur }\end{array}$ & $\begin{array}{l}\text { Trespasser in an unfamiliar } \\
\text { domain }\end{array}$ & Across multiple domains & Transposition \\
\hline
\end{tabular}

